\title{
FLOWERING PHENOLOGY OF MEDITERRANEAN QUERCUS SPECIES IN DIFFERENT LOCATIONS (CÓRDOBA, SW IBERIAN PENINSULA)
}

\author{
$\mathrm{M}^{\mathrm{a}}$ Teresa GÓMEZ-CASERO ${ }^{1 *}$, Carmen GALÁN ${ }^{1}$ \\ and Eugenio DOMÍNGUEZ-VILCHES ${ }^{1}$
}

\begin{abstract}
${ }^{1}$ Departamento de Biología Vegetal, Facultad de Ciencias, Campus universitario de Rabanales Universidad de Córdoba, E-14071. Córdoba.

*Corresponding author: bv2gogom@uco.es
\end{abstract}

Recibido el 13 de julio de 2007, aceptado para su publicación el 28 de septiembre de 2007

Pulicado "on line" en octubre de 2007

\begin{abstract}
Flowering phenology of Mediterranean Quercus species in different locations (Córdoba, $S W$ Iberian Peninsula). Periodical qualitative and quantitative checking of flowering phases was carried out over six growing seasons (1997-2002) for the three Mediterranean Quercus species found in Sierra Morena (Córdoba, SW Spain): Q. ilex L. ssp. ballota (Desf.) Samp., Q. coccifera L. and $Q$. suber L. A total of 60 individuals were selected. Additionally, 30 Quercus ilex ssp. ballota individuals were selected and studied in Sierras Subbéticas (Priego de Córdoba, SW Spain) in 1999 and 2000. Morphological changes occurring at different points in each phenological phase were charted. Among species differences were found for inflorescences/male and female flowers, in terms of the phenological flowering sequence. Male inflorescences displayed a more homogeneous development. All individuals and populations were proterandrous. Phenological trends and ranges were charted. Although trends varied with species and year, the overall phenological trend seemed to fit a sigmoid curve in all cases, increasing with phenological development. Shorter ranges were obtained in years with warmer springs, and longer ranges in colder years. Moreover, phenological range differed as a function of species and location. In general, $Q$. ilex ssp. ballota flowered earlier than the rest, $Q$. suber displaying the latest flowering period. Individuals located at lower altitudes and facing the sun flowered earlier, followed in most years by those located at higher altitudes. Thus, $Q$. ilex ssp. ballota flowered earlier in Sierra Morena than in the higher-altitude Sierras Subbéticas.
\end{abstract}

Key words. Flowering, Quercus, reproductive phenology, range, tendency.

RESUMEN. Fenología floral de tres especies mediterráneas de Quercus en diferentes localidades (Córdoba, Suroeste Península Ibérica). Se ha realizado un seguimiento periódico cuantitativo y cualitativo de las fenofases florales de tres especies mediterráneas de Quercus localizadas en Sierra Morena (Córdoba, suroeste de España) por un periodo total de seis años (1997-2002): Q. ilex L. ssp. ballota (Desf.) Samp., Q. coccifera L. y Q. suber L. Se seleccionaron un total de 60 individuos de las tres especies. Adicionalmente, un total de 30 individuos de Quercus ilex ssp. ballota fueron seleccionados y estudiados en las Sierras Subbéticas (Priego de Córdoba, suroeste de España) durante los años 1999 y 2000. Se estudiaron los cambios morfológicos ocurridos en cada fase fenológica. Se encontraron diferencias en el desarrollo fenológico entre inflorescencias/flores masculinas y femeninasen las diferentes especies estudiadas. Las inflorescencias masculinas mostraron un desarrollo más homogéneo. Todos los individuos y las poblaciones fueron proterandros. Las tendencias y 
amplitudes fenológicas fueron representadas gráficamente. Aunque las tendencias variaron en función de la especie y el año considerado, la tendencia general en todos los casos, se asemejó a una curva sigmoide aumentando su pendiente a medida que avanza su desarrollo fenológico. Las amplitudes fenológicas más cortas se obtuvieron los años con primaveras más cálidas, y las mayores en las más frías. Además, la amplitud fenológica fue diferente en función de la especie y la localización de los individuos. En general, $Q$. ilex ssp. ballota floreció antes que el resto, $Q$. suber presentó el periodo de floración más tardío. Los individuos localizados a menores altitudes y los dispuestos en dirección al sol florecieron antes, seguidos la mayoría de los años por aquéllos situados en altitudes mayores. De esta forma, $Q$. ilex ssp. ballota floreció antes en Sierra Morena que en las Sierras Subbéticas situadas a mayor altitud.

Palabras clave. Floración, Quercus, fenología reproductiva, amplitud, tendencia.

\section{INTRODUCTION}

Classical phenology is the art of subdividing the development of biological taxa into identificable sections along a time axis (Lieth 1997). These sections are termed phenophases, and are used to monitor the development of the life cycle of an organism. The occurrence of a phenophase is determined by the biotic characteristics of the plant species, and by local climate characteristics (Orshan, 1989). At the same time, climate variations influence flowering periods in many species (Zerboni et al. 1991, Puppi Branzi and Zanotti 1992). Nowadays, floral phenology includes the study of periodic events as influenced by the environment, especially temperature changes driven by weather and climate (Schwartz, 2003). Phenological behaviour varies from year to year, since weather conditions are not always the same; phenological observations must therefore be carried out over a number of years, in order to obtain a general overview. Floral phenological changes in anemophylous communities appear to fit a sigmoid pattern that may be approximated by a logistic equation (Latorre 1997). This pattern is associated with a progressive increase in temperatures that affects different phenophases in different ways (PérezLatorre and Cabezudo, 2002).

Phenology has recently emerged as an important focus of ecological research (Schwartz, 1999). Over recent years a wide range of applications have been developed. The forecasting of plant phenological phases is of great value in various areas of research - agriculture, public health, ecology, fitoclimatology, climate change - in which phenological data play a key role. At the same time, high levels of greenhouse gases detected in the air are evidently changing the earth's climate (Lieth, 1997); one of the main consequences will be a disturbance in the annual cycle of plants, and especially in the onset of the active period in spring (Myking and Heide 1995). Budburst could be brought forward in time, rendering buds more vulnerable to late spring frosts; alternatively, budburst could be delayed, thereby possibly not making full use of the available growing season (Myking and Heide 1995; Kramer 1997; Sparks et al. 2000). This could lead to changes in the geographical distribution of species and in forest composition (Kramer, 1997). Research into flowering phenology is a complementary tool in climate studies. Moreover, definition of the phenological phases of male and female flowering in dioecius species is essential in order to highlight the role of reproductive biology in breeding and gene-conservation programs (Varela and Valdiviesso 1996).

On the other hand, several studies have been focused on the characterization and 
comparison of the phenology of different plant communities and plant species in Mediterranean-type ecosystems (PérezLatorre and Cabezudo, 2002), as well as on the study of their phenomorphology and ecomorphological characters (Pérez-Latorre and Cabezudo, 2006). A study of Mediterranean vegetation based on growth forms and phenological phases can make a great contribution to existing classifications (ecological, physiognomic, phytosociological, etc. (Pérez-Latorre and Cabezudo, 2006)) and understanding phenological vegetative and reproductive behaviours and adaptations.

Field observations of floral development enable the major phases in the biological flowering process to be charted. A number of studies addressing Quercus floral biology focus on the morphology and diversity of the reproductive organs (Kaul 1985), the life cycle (Ducousso et al. 1993; Elena-Rosello et al. 1993; Oliveira et al. 1994), flowering (Varela and Valdiviesso 1996), and embryogenesis (Stairs 1964). The temporal distribution of phases discerned in the development of reproductive structures represents floral phenological development. Each of these stages is clearly differentiated and defined, both morphologically and physiologically, on the basis of inflorescence development from undifferentiated bud to catkin senescence or fruit formation (Varela and Valdiviesso 1996; Vázquez 1998). The ripening fruit is partially covered by the developing cupule (Kaul 1985), as although Q. ilex ssp. ballota, however in $Q$. coccifera a larger fraction of fruit was covered.

Quercus species, the most spread tree species of the Mediterranean forests, are dichogamous, and more particularly proterandrous, which enhances successful crossing between individuals of the same population and even between different species (Vázquez 1998). The reproductive biology in this group includes two different types of seed cycles: the "annual biotype", that requires only one season to complete its reproductive cycle, and the "biennial biotype" which requires two full years. This complex reproductive behaviour may account to some extent for the lack of detailed knowledge of these species (Varela and Valdiviesso 1996). Moreover, there is a lack of information regarding Quercus behaviour across an altitudinal gradient of growth and over several years.

From an ecological standpoint, forest dynamics and structure depend on the reproductive phenology of woody species. In the «dehesas» - traditional, semi-natural, man-made systems found throughout the Iberian Peninsula and especially in southwestern Spain - predominant evergreen Quercus are associated with cereal crops and grasslands that play a major role in avoiding soil erosion, increasing soil fertility and providing for genetic variability (Campos Palacín 1991; Joffre 1991). In the southern Spanish province of Córdoba, evergreen Quercus are also found in association with other wild species, as part of a predominant natural landscape (Pérez-Latorre et al., 1993).

This study was carried out in the mountains of Córdoba, where Quercus is widespread: $Q$. ilex ssp. ballota (Desf.) Samp is the most abundant species, while $Q$. coccifera $\mathrm{L}$. is marginally less common; $Q$. suber L. is abundant in wetter areas. These three evergreen species are typical of Mediterranean climate zones in the Mediterranean Basin. Both Q. ilex ssp. ballota and Quercus suber are of economic importance, since their acorns are a major food source for certain animal species vital to the region's economy: pigs, bulls and deer. The economic value of Quercus suber is enhanced by cork production. This study charted floral phenology in all three Quercus species, which are the most abundant in the 
study area.

The purposes of the study were: (1) To standardize the external development of male and female flowers in the three Quercus species studied; (2) To determine the phenological behaviour at four different locations over six years; (3) To compare the phenological behaviour of $Q$. ilex ssp. ballota in two populations located at different altitudes.

\section{MATERIALS AND METHODS}

\section{Study area}

Locality A

The city of Cordoba $\left(37^{\circ} 55^{\prime} \mathrm{N}, 4^{\circ} 45^{\prime} \mathrm{W}\right.$, $123 \mathrm{~m}$ above sea level) is located in the Southwest of the Iberian Peninsula in the fertile lowland of the river Guadalquivir, between Sierra Morena, in the North, and a flat expanse of arable land and Sierra Subbética, in the South. The climate is Mediterranean, with a touch of continentality; the average annual temperature is $18^{\circ} \mathrm{C}$, and average annual rainfall is $600 \mathrm{~mm}$, based on 40-year data from the Spanish National Institute of Meteorology.

The study was run over six consecutive years (1997-2002) in the foothills of the Sierra Morena; vegetation is characteristically thermophilic, with a mixture of Quercus ilex ssp. ballota, Quercus coccifera and a fairly well-preserved population of Quercus suber.

\section{Locality $B$}

Additionally, Quercus ilex ssp. ballota was studied over a two-year period (19992000) in a mountainous area of Priego de Córdoba, a city in the province of Córdoba located in the Sierra Subbética Natural Park ( $37^{\circ} 26^{\prime} \mathrm{N}, 4^{\circ} 11^{\prime} \mathrm{E}, 900 \mathrm{~m}$ above sea level). The average annual temperature is $14.4^{\circ} \mathrm{C}$, and average annual rainfall is $765 \mathrm{~mm}$, based on 40-year data from the Spanish National Institute of Meteorology. Due to its altitude,
Priego de Córdoba is wetter and colder than Córdoba. The vegetation of the zone is thermophilic with a mixture of Paeonia coracea, Paeonia broteroi, Pistacia lentiscus, and Quercus ilex ssp. ballota.

Meteorological data were supplied by the Meteorological Network based in the city of Córdoba.

\section{Methodology \\ Study plots}

A total of 60 mature, well-developed individuals of the three Quercus species were selected in four different areas of the Sierra Morena, located at different heights and different orientations relative to the sunfacing:

Zone 1 (Medina Azahara): Q. ilex ssp. ballota grove located near Medina Azahara (Arab ruins), with the following coordinates: UTM 30S UG 3495. The area is $270 \mathrm{~m}$ above sea level, and sunny. Ten Quercus ilex ssp. ballota individuals were selected.

Zone 2 (El Cruce): Q. ilex ssp. ballota grove located half-way between Medina Azahara and Las Ermitas, with the following coordinates: UTM 30S UG 3998. This area is $440 \mathrm{~m}$ above sea level, and sunny. Ten Quercus ilex ssp. ballota and ten Quercus coccifera individuals were selected.

Zone 3 (Las Ermitas): Q. suber grove located between Las Ermitas and Lagar de la Cruz, with the following coordinates: UTM 30S UH 3800. This area is $520 \mathrm{~m}$ above sea level, shady. Ten Quercus suber individuals were selected.

Zone 4 (El Lagar): Q. suber grove - $Q$. ilex ssp. ballota grove located between Lagar de la Cruz and the crossroad with El Brillante, with the following coordinates: UTM 30S UH 3800 . Height $550 \mathrm{~m}$ above sea level, sunny. Ten Quercus suber and ten Quercus ilex ssp. ballota were selected.

Q. coccifera are typical of degraded 
soils, and the area in which they are found (Zone 2) displays strong housing pressure. For this reason, only a small population of well-preserved individuals was available for study.

Quercus suber is present in mountainous areas, in the highest and wettest zones; it was thus only present in Zones 3 and 4 of the study. Q. ilex ssp. ballota is more common over the whole area, as it is better adapted to local bioclimatic conditions; it was therefore present in more zones.

Additionally, 30 Quercus ilex ssp. ballota trees were selected in Priego de Córdoba (Sierras Subbéticas). These individuals were located in three different zones, with varying relative exposure to the sun: Zone 1 (North-facing hillside); Zone 2 (Watercourse); and Zone 3 (South-facing hillside).

\section{Phenology}

For monitoring population phenology, several trees were selected for each Quercus species to reflect optimal development and normal seasonality. Each individual was assigned an identification number. Field work consisted in weekly visits to individual zones at the start of the flowering season, and twice-weekly visits during maximum flowering and the fruit-formation period. Samplings were carried out over six consecutive years in Sierra Morena and two consecutive years in Sierras Subbéticas, from January to July, when flower development and fruit formation take place. On each visit, branches and whole crown were observed, and the phenological phase noted.

Additionally, samples were taken from the first floral traces (first buds) right through to formed fruit, except for $Q$. coccifera whose fruits ripen in the next growing season. In 1997, sampling commenced on 12 February, thus, in some cases there is no information on the initial phenological phases. Samples taken in the field and labelled were later analysed in the laboratory. Buds, flowers and fruits were observed with a magnifying glass; morphological data were recorded; the longitudinal size of buds, flowers and catkins was measured. For these measurements, an average of 30 elements was used. Finally, a phenological herbarium was developed using the field samples collected, for reference purposes.

A series of floral phases was established, each phase being designated by a letter. Capital letters were used for male flower phases, and lower-case letters for females. Description of phenological phases was based on previous studies of Quercus suber (Varela and Valdiviesso 1996) in Portugal and Quercus ilex ssp. ballota (Vázquez 1998) in Extremadura (NW Spain), in order to provide a standardized sequence of reproductive phases for the three species studied here.

Reproductive phenophases were used as a tool to study Quercus phenological behaviour in the study areas. For quantitative characterization of floral phenophases, a number from 1 to 8 was assigned to each phase. A tree was assigned to a given phase when at least $50 \%$ of the crown was in that phase (Varela and Valdiviesso 1996). Phenophases per individual were recorded in Microsoft Excel files, and the average daily values of phenological phases were calculated for each population at different sampling dates. Floral phenological tendency and range were charted, and results for years and populations were compared.

\section{RESULTS}

\section{Phenological phases}

Male and female floral development followed different patterns, and morphological changes were evident both 
between and within the two types of inflorescence as a function of developmental stage. A total of eight phenological phases were described for male and female flowering, covering the full morphological development for each species (fig. 1).

\section{Male flowering}

Male flowers occurred in catkins emerging in reproductive buds at the top of the previous season's branches and at the base of current-season branches. Anthers did not burst simultaneously. Eight different phenophases were defined for the three Quercus species studied.

A-Closed bud: this corresponds morphologically to the swollen bud, of 1-2 $\mathrm{mm}$. Brownish-grey closed buds could not be differentiated from vegetative buds. This phase is simultaneous with the development of the first vegetative buds.

B-Bud development: in this phase, the bud was larger, up to 2-4 $\mathrm{mm}$. Bud development commenced. A varying number of meristematic structures were seen to be developing at the same points.

C-Catkin development: erect catkins. A short, bare pedicel; the remainder of the catkin could be discerned. Quercus ilex ssp. ballota and Quercus coccifera showed yellow catkins and Quercus suber showed purple catkins. Flowers could still be distinguished due to tight clustering. Catkin size was no larger than $1 \mathrm{~cm}$.

D-Catkin elongation: growth of the inflorescence axis. Catkins were up to $2 \mathrm{~cm}$ in length. Erect catkins and closed flowers were distinguishable along the axis.

E-Start of flowering: pendant yellow catkins. Catkin growth ceased. Flowers in anthesis; anthers mostly closed, although up to $20 \%$ of flowers were releasing pollen.

F-Full flowering: most flowers (20$80 \%)$ shedding pollen. Some flowers were starting to wither following pollen release.
G-Senescence: over 50\% of flowers had stopped releasing pollen; catkins had turned brown to drying-out of most anthers.

H-Catkin fall: flowering completely over, only dried-out catkins left on branches, now starting to fall.

\section{Female flowering}

Female Quercus flowers are arranged in spikes on the axils of new-growth leaves. Spike axis growth lasts over several days, giving rise to continuous flower formation. Eight different phenophases were defined for the three Quercus species (fig. 1).

a-Closed bud: whitish, pilose reproductive axillary buds, about 1-2 mm long, only visible through a magnifying glass.

b-Inflorescence development: first spikes occurred on axils of new leaves. Closed flowers were visible as small pilose swellings $1 \mathrm{~mm}$ in length, only visible through a magnifying glass.

c-Flower differentiation: female flowers displayed erect greenish styles. Pilose bracts, visible at the flower base, flowers up to 2 $\mathrm{mm}$ in length.

d-Full flowering and receptivity: fullyformed female flowers distinguishable inside the inflorescence. Over $50 \%$ of flowers in the spike displayed shiny, yellowish-white, viscous stigmas. Full receptivity.

e-Stigma oxidization: Increased flowers size. Stigmas turned dull brown by oxidization. Flowers had not yet lost receptivity.

f-Loss of receptivity: considerable increase in flower size. Future pericarp of the fruit visible above developing cupule. The bracts of the incipient cupule were of membranous consistency. Stigmas, which were black and hard, had lost their receptivity.

g-Fruit formation: fruit now formed. Woody consistency of the cupular bracts, all 


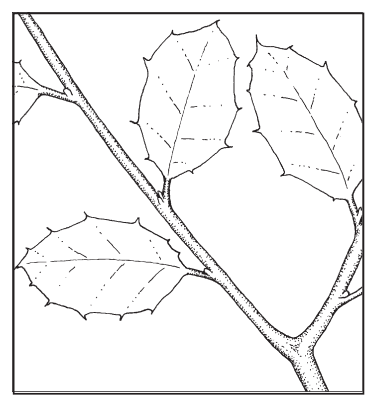

A

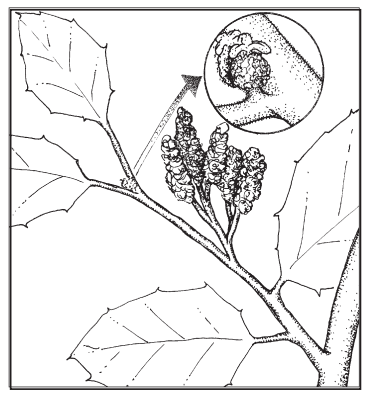

D/c



G/f

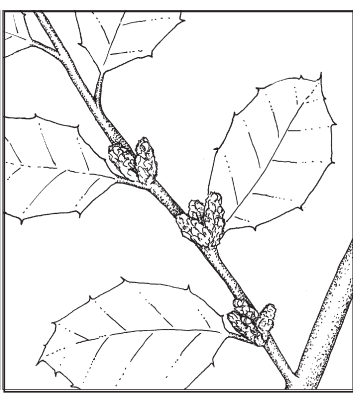

B/a



E/d



H/g

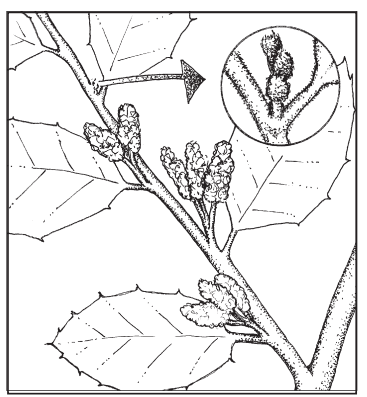

$\mathrm{C} / \mathrm{b}$

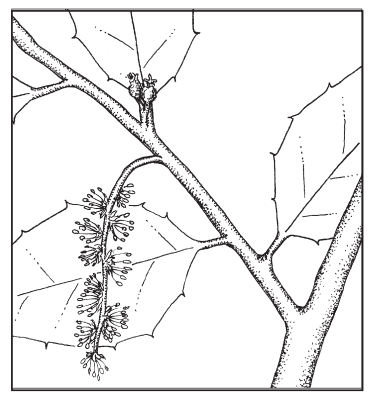

F/e

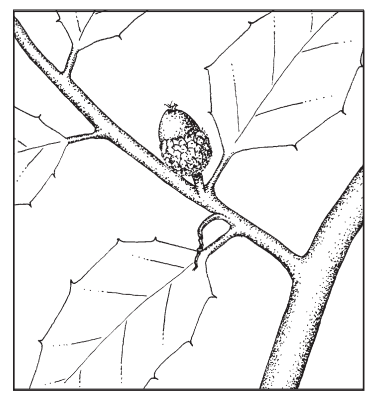

h

Figure 1. Flower development. Male and female floral phenophases in Quercus: A. Closed bud, B. Bud development, C. Catkin development, D. Catkin elongation, E. Start of flowering, F. Full flowering, G. Senescence, H. Catkin fall, a. Closed bud, b. Inflorescence development, c. Flower differentiation, d. Full flowering and receptivity, e. Stigma oxidization, f. Loss of receptivity, g. Fruit formation, h. Fruit development. Fenofases florales masculinas y femeninas en Quercus. A. Yema cerrada, B. Desarrollo de la yema, C. Desarrollo del amento, D. Elongación del amento, $\boldsymbol{E}$. Inicio de la floración, $\boldsymbol{F}$. Plena floración, $\boldsymbol{G}$. Senescencia, $\boldsymbol{H}$. Caída de amentos, $\boldsymbol{a}$. Yema cerrada, $\boldsymbol{b}$. Desarrollo de la inflorescencia, $\boldsymbol{c}$. Diferenciación de la flor, $\boldsymbol{d}$. Plena floración y receptividad, $\boldsymbol{e}$. Oxidación del estigma, $\boldsymbol{f}$. Pérdida de la receptividad, $\boldsymbol{g}$. Formación del fruto, $\boldsymbol{h}$. Desarrollo del fruto. 
studied species displayed characteristic cupular shape.

h-Fruit development: Fruit developed.

There was generally some overlap between full receptivity in a single female and the start of male flowering. However, not all members of a given population flowered simultaneously. Phenophases did not always coincide: thus, when one individual was at the start of the flowering period, another was at the end of that period. All selected individuals displayed fertile male and female flowers simultaneously.

Inter-species differences were found for catkins and spikes in terms of the phenological flowering sequence, although male inflorescences displayed a more homogeneous development. Spikes had far fewer flowers, and displayed a gradient of growth from base to tip; basal flowers were usually at a more advanced phenological stage. Three or more different phenological stages were sometimes apparent within the same inflorescence.

Although phenological development was similar in the three evergreen species studied, several floral morphological differences were observed. Catkin length varied considerably: catkins in $Q$. ilex ssp. ballota were up to $10-12 \mathrm{~cm}$ long, compared to $15-17 \mathrm{~cm}$ in $Q$. suber and $4-7 \mathrm{~cm}$ in $Q$. coccifera. On spikes, the number of flowers per inflorescence ranged between 1 and 9 . Female flowers in anthesis were partially embedded in the developing cupule. The ripening fruit was partially covered by the cupule; in $Q$. coccifera a larger fraction of fruit was covered.

Inflorescences and fruits occurred on new branches in all selected $Q$. ilex ssp. ballota and $Q$. suber individuals, in $Q$. coccifera inflorescences and fruits were observed both on new branches and on previous-year branches, since fruit requires two years to ripen.
The $Q$. ilex ssp. ballota flowering process in Priego de Córdoba was similar to that observed for the same species in Sierra Morena in 1997; however, in 2000 most individuals in Zone 1 (north-facing hillside) produced only vegetative buds.

\section{Phenological tendency}

Sierra Morena

Figure 2 shows average phenologicaltendency curves, reflecting average numerical values assigned to the various phenological stages (male and female) described above for each of the three Quercus species studied (Q. ilex ssp. ballota, Q. coccifera and Q. suber) from 1997 to 2002. The Y-axis represents phenological values and the $\mathrm{X}$-axis the sampling date for each study year. The phenological tendency was studied from January to June for $Q$. ilex ssp. ballota and Q. coccifera, and from February to early July for Q.suber, except in 1997, when samplings of all species began in February. Phase number 8 corresponds to the end of male and female phenological sampling, and covers the period to the last sampling day.

Although the tendency varied among species and years, the general phenological tendency seemed to fit a sigmoid curve in all cases, rising with time; the slope depended on the consecutive start of the various phenophases. Slow development in the initial phases was followed by fast changes during the flowering period. Moreover, phase to phase transition was not gradual in some cases, probably due to meteorological changes or sampling frequency; as a result, the curve has a staggered appearance (fig. 2).

\section{Sierras Subbéticas}

Figure 2 shows phenological tendency curves reflecting the average numerical 
Q. ilex ssp. ballota

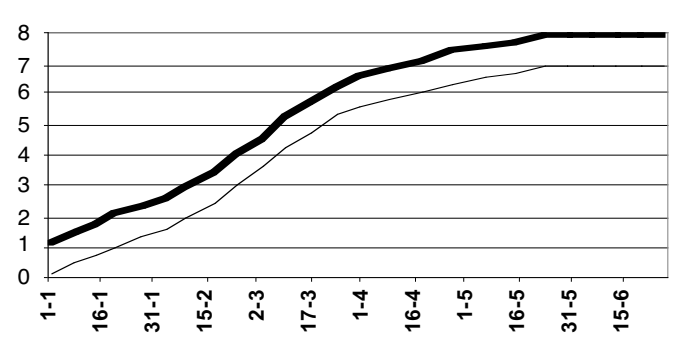

Male - Female
Q. coccifera
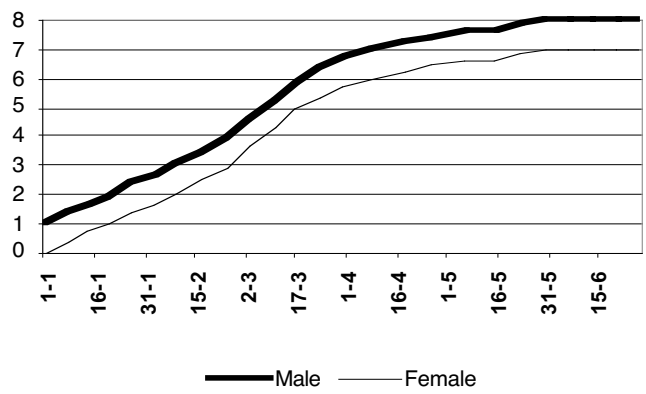

Q. suber

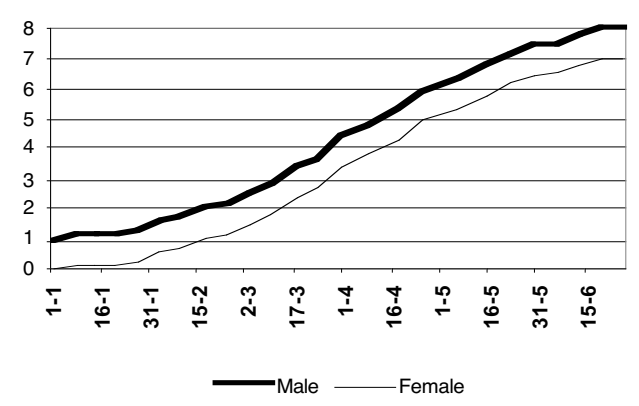

Sierras Subbéticas

Q. ilex ssp. ballota

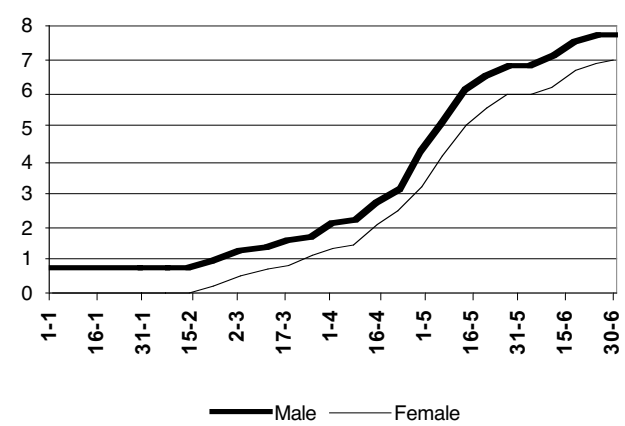

Figure 2. Average phenological tendency curves of the three Quercus studied species in Sierra Morena and $Q$. ilex ssp. ballota in Sierras Subbéticas. Y-axis: 1. Phenophase A; 2. Phenophase B/a; 3. Phenophase C/b; 4. Phenophase D/c; 5. Phenophase E/d; 6. Phenophase F/e; 7. Phenophase G/f; 8. Phenophase H/g. X-axis: Date. Curvas de la tendencia fenológica media de las tres especies de Quercus estudiadas en Sierra Morena y Q. ilex ssp. ballota en las Sierras Subbéticas. Eje-Y: 1. Fenofase A; 2. Fenofase B/a; 3. Fenofase C/b; 4. Fenofase D/c; 5. Fenofase E/d; 6. Fenofase F/e; 7. Fenofase G/f; 8. Fenofase H/g. Eje-X: Fecha. 

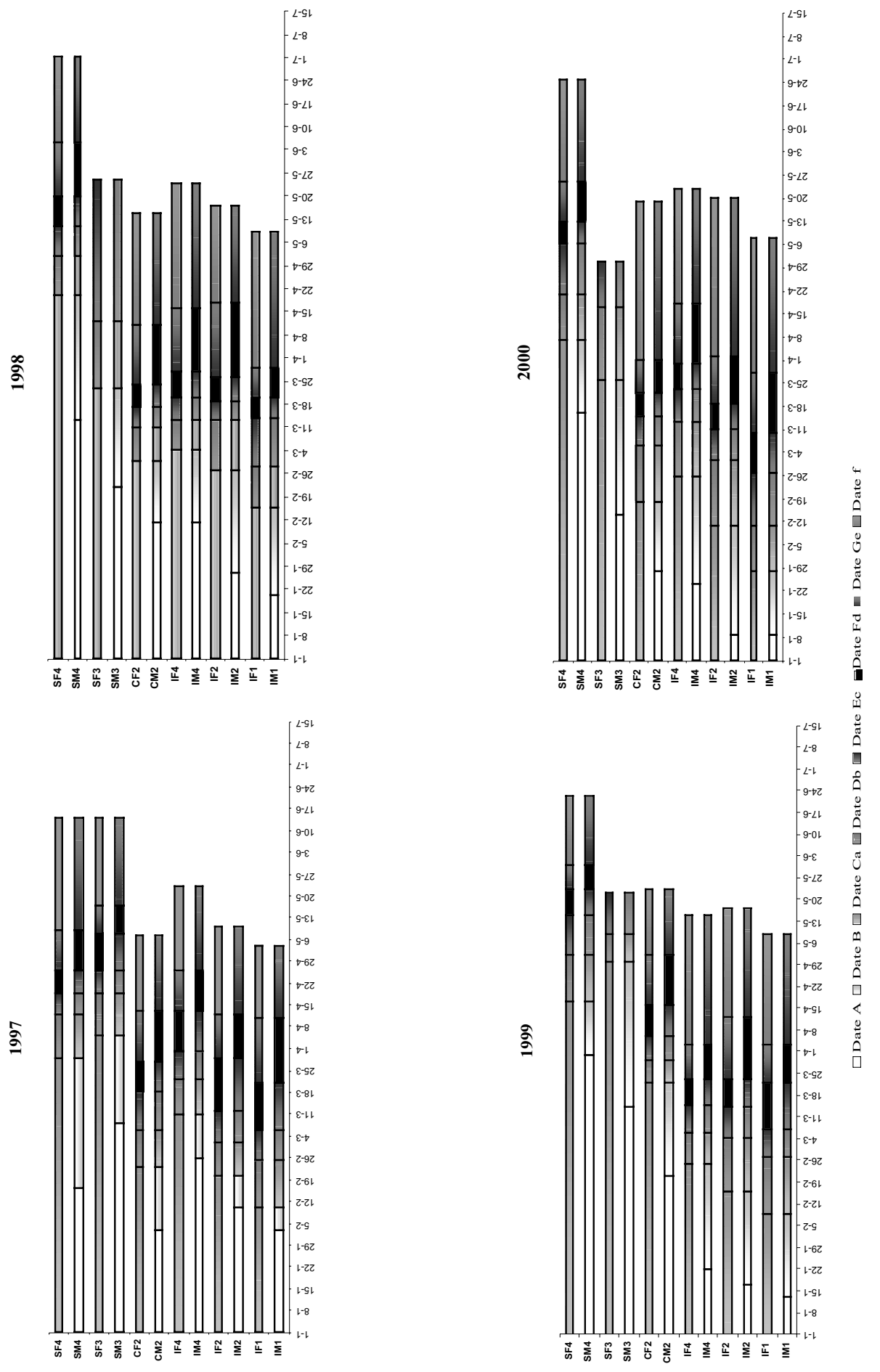

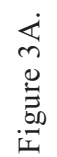




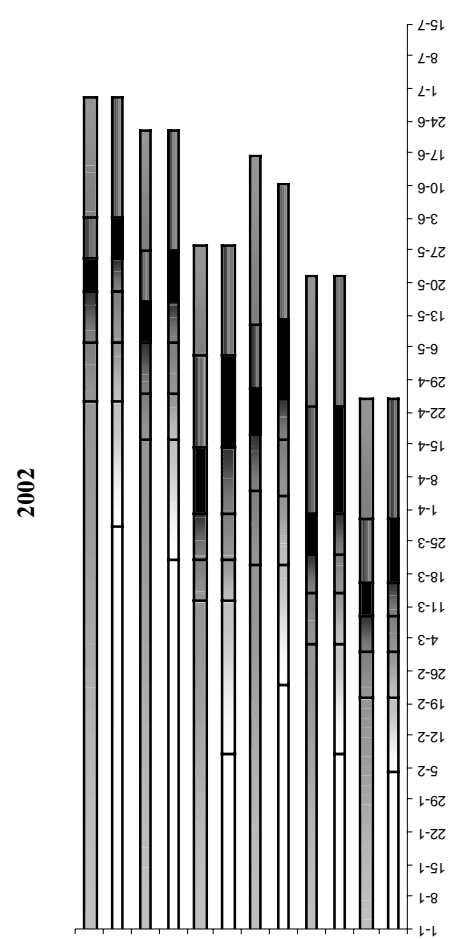

نัต

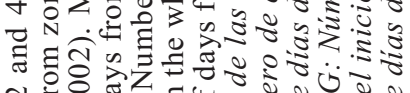

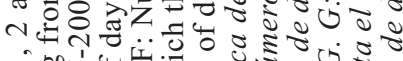
7.

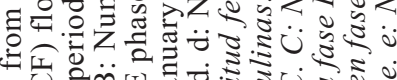

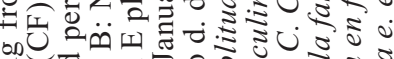




눈.

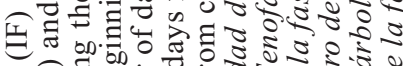

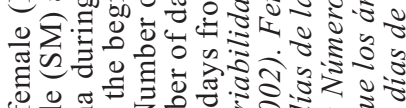

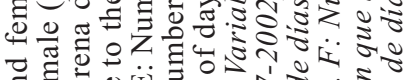
चี

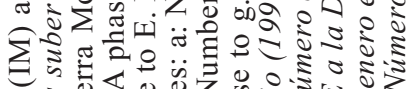

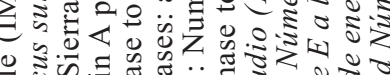

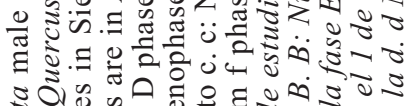

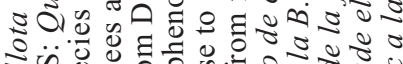

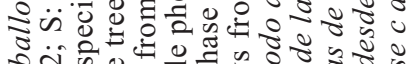
उतi की

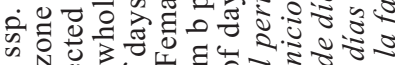

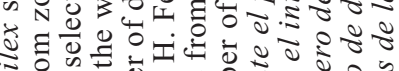



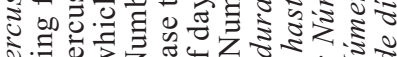



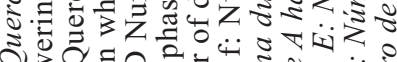

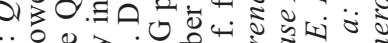

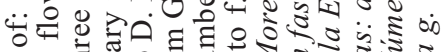

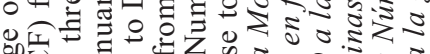

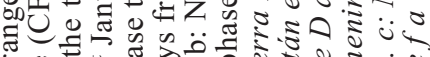

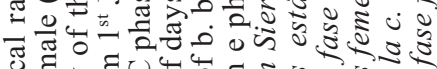

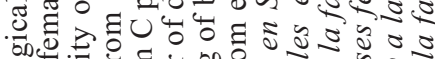

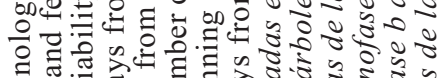


a.

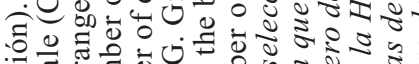

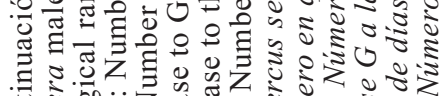

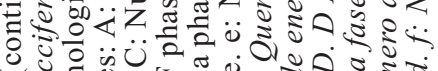

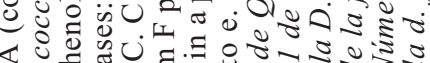
<ن

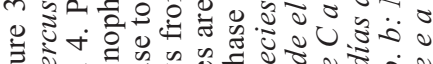

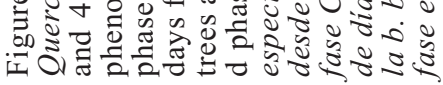


1999

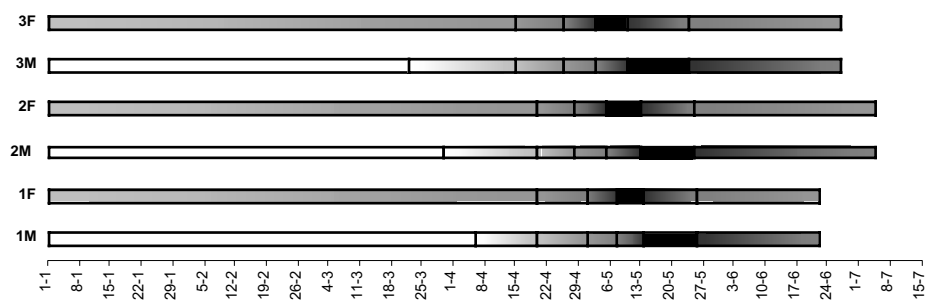

2000



Figure 3B. Phenological range of Quercus ilex ssp. ballota male (M) and female (F) flowering from zone 1, 2 and 3. Phenological range variability of the three Quercus ilex ssp ballota selected zones in Sierras Subbéticas during the studied period (1999-2000). Male phenophases: A: Number of days from $1^{\text {st }}$ January in which the whole trees are in A phase to the beginning of B. B: Number of days from B phase to C. C: Number of days from C phase to D. D Number of days from D phase to E. E: Number of days from E phase to F. F: Number of days from F phase to G. G: Number of days from G phase to H. Female phenophases: a: Number of days from $1^{\text {st }}$ January in which the whole trees are in a phase to the beginning of $b$. b: Number of days from $b$ phase to $c$. $c$ : Number of days from $c$ phase to d. d: Number of days from d phase to e. e: Number of days from e phase to f. f: Number of days from $\mathrm{f}$ phase to g. Variabilidad de la amplitud fenológica de las tres zonas selccionadas de Quercus ilex ssp ballota en las Sierras Subbéticas durante el periodo de estudio (1999-2000). Fenofases masculinas: A: Número de días desde el 1 de enero en que los árboles están en fase A hasta el inicio de la B. B: Número de días de la fase B a la $C$. C: Número de días de la fase C a la D. D Número de días de la fase $D$ a la E. E: Número de días de la fase E a la D. F: Número de días de la fase F a la G. G: Número de días de la fase $G$ a la H. Fenofases femeninas: a: Número de dias desde el 1 de enero en que los árboles están en fase a hasta el inicio de la b. b: Número de dias de la fase $b$ a la $c$. c: Número de días de la fase c a la d. d Número de dias de la fase d a la e. e: Número de días de la fase e a la d. f: Número de días de la fase $f$ a la $g$.

values given to the various phenological stages (male and female) of $Q$. ilex ssp. ballota for the three study zones in Priego de Córdoba over both study years (19992000). The general phenological tendency appeared to fit a sigmoid curve. However, the phenological tendency during 2000 in Zone 1 (north-facing hillside), displayed a sharper slope; phase to phase transition was more abrupt due to the lack of data, since only two trees in that zone flowered in 2000 - the other trees in Zone 1 produced only vegetative buds.

\section{Phenological range}

Sierra Morena: Inter-species and Interannual variability

Figure 3 A shows bar charts for temporal distribution range of male and female phenological phases in the Sierra Morena 


\begin{tabular}{lccccccc}
\hline SPECIES & Zone & 1997 & 1998 & 1999 & 2000 & 2001 & 2002 \\
\hline & $(1)$ & 125 & 130 & 130 & 129 & 145 & 116 \\
Q. ilex ssp. ballota & $(2)$ & 131 & 138 & 138 & 141 & 155 & 142 \\
& $(4)$ & 144 & 145 & 136 & 144 & 156 & 163 \\
Q. coccifera & $(2)$ & 128 & 136 & 144 & 140 & 141 & 149 \\
Q. suber & $(3)$ & 166 & $146^{*}$ & $143^{*}$ & $122^{*}$ & 153 & 174 \\
& $(4)$ & 166 & 183 & 174 & 177 & 176 & 181 \\
\hline
\end{tabular}

Table 1. Flower development total length for each one of the species during the studied period (19972002) in Sierra Morena (number of days from the beginning to the end,). (*): Data up to D/c phenophase. Amplitud total del desarrollo floral para cada una de las especies durante el periodo de estudio (1997-2002) en Sierra Morena (número de días desde el comienzo hasta el final). (*): Datos hasta la fenofase D/c.

area (zones 1, 2 and 4), based on the development of the buds/flowers pool. Phenological range is the number of days that a concrete phenophase lasts. This figure shows the inter-species and inter-annual male and female floral phenological range for Quercus over the study period (19972002).

The $\mathrm{Y}$ axis represents species by sex and zone, while the $\mathrm{X}$ axis represents sampling dates from 1 January to the last day of sampling.

Inter-species and inter-annual differences in phenological range were observed for every phenophase. In all three species, the longest phenophase every year was bud development in both sexes. Once flowering was over, the male senescence phenophase and the female loss-ofreceptivity phase were the longest. In most years, full flowering was shorter in females than in males.

The flowering period in $Q$. ilex ssp. ballota and Q. coccifera was earlier (second fortnight in April) than that of $Q$. suber (late April-May) (fig. 3A).

Although double flowering was not a general finding in the study area, some $Q$. ilex ssp. ballota and $Q$. suber trees displayed a second (male or female) flowering period at the start of autumn in both 1999 and 2001.
This second flowering was probably due to mild temperatures and higher rainfall, following a stress period caused by harsh summer conditions. However, doubleflowering was not completed, and stopped in phenophase $\mathrm{D} / \mathrm{c}$.

Some differences were apparent between members of the same species, as a function of location. Comparison of the temporal distribution of phenophases between $Q$. coccifera and $Q$. ilex ssp. ballota in Zone 2, where both species are abundant, revealed that flowering periods occasionally overlapped, but on other occasions were separated by an interval of up to 10 days. In 1999, Q. coccifera flowered 24 days later than $Q$. ilex ssp. ballota in the same zone, probably due to poor rainfall over the previous months, which may have had a more negative impact on $Q$. coccifera as a shrub.

Male phenological development in $Q$. suber was anomalous in 1998, 1999 and 2000 in zone 3 , where none of the selected trees completed the reproductive cycle. Catkins which were already formed and had differentiated flowers, withered and the flowers failed to open out (fig.3A). Temporal distribution of phenophases in this species was normal from the start of elongation to the catkin stage, at which point catkins 

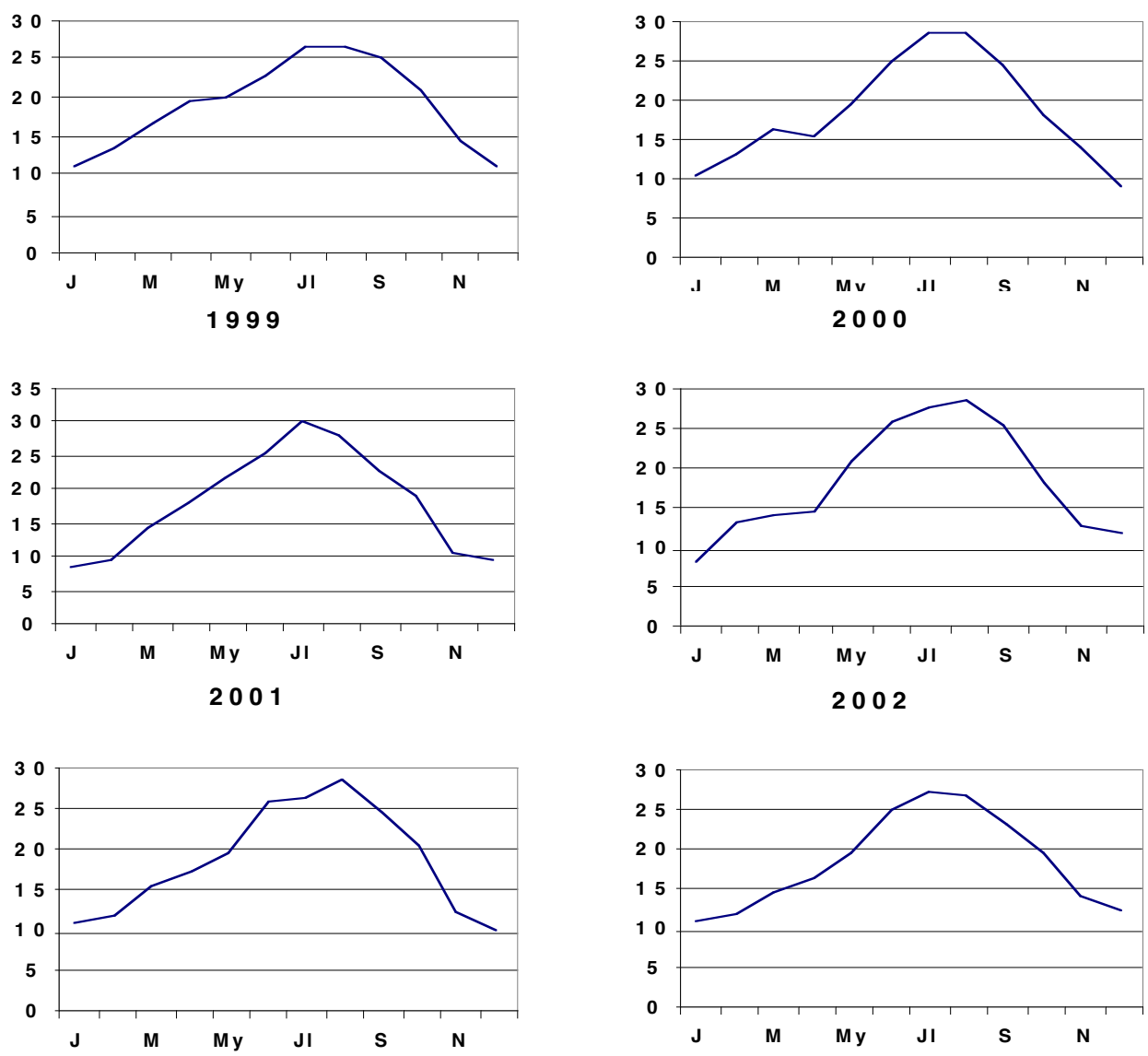

1999

2000


Figure 4. Monthly average temperature for the studied years: 1997-2002 in Sierra Morena; 19992000 in Sierras Subbéticas. Distribución mensual de las temperaturas medias para cada uno de los años de estudio: 1997-2002 en Sierra Morena; 1999-2000 en Sierras Subbéticas. 


\begin{tabular}{lcc}
\hline & \multicolumn{2}{c}{ YEAR } \\
ZONE & 1999 & 2000 \\
\hline North hillside & 174 & 158 \\
Watercourse & 187 & 165 \\
South hillside & 179 & 167 \\
\hline
\end{tabular}

Table 2. Flower development total length of $Q$. ilex ssp. ballota for each one of the sampling zones during the studied period (1999-2000) in Sierras Subbéticas. Amplitud total del desarrollo floral de Q. ilex ssp. ballota para cada una de las zonas de muestreo durante el periodo de estudio (1999-2000) en las Sierras Subbéticas.

development ceased and catkins assumed a senescent appearance. The length of phase $\mathrm{D}$ in those years coincided with occurrence of catkin senescence.

In early spring of 1998, 1999 and 2000 years, sharp falls in temperature were recorded (fig. 4). In Córdoba, unusually low temperatures coincided with development of male phenophase D. In March 1998, minimum temperatures fell to as low as $2.8^{\circ}$ and $1.8^{\circ} \mathrm{C}$, and a mean temperature of around $10^{\circ} \mathrm{C}$ were recorded. Early-spring weather conditions were similar in 1999 and 2000. Zone 3 trees are located in a shady zone and therefore low temperatures caused more devastating damage to developing plant structures. Table 2 shows the total range of the flowering period for each Quercus species in the different sampling zones indicated for all six study years, expressed as number of days from 1 January to the end of the flowering period. Values for phenological range differed for each sampling zone and study year. Shorter ranges were obtained in years with warmer springs and longer ranges in colder years. Phenological range in $Q$. ilex ssp. ballota from zone 1 was shorter because it is a sunny zone located at a lower altitude; in most years, trees in zone 4, at a higher altitude, showed a longer range. Over the two last years, $Q$. suber showed a greater total phenological range in zone 4 than in the lower-altitude zone 3 (tab.1).

\section{Sierra Morena: Inter-zone intra-species variability \\ Within the same species those} individuals located at lower altitudes flowered before those located at higher altitudes. Q. ilex ssp. ballota from zone 1 $(270 \mathrm{~m})$ flowered first, followed by trees in zone $2(440 \mathrm{~m})$ and finally those in zone 4 $(550 \mathrm{~m})$. With regard to $Q$. suber, trees in zone $3(520 \mathrm{~m})$ flowered first, followed by trees in zone $4(550 \mathrm{~m})$, with the exception of 1997. Results for 1998, 1999 and 2000, when flowering development was truncated, were not taken into account. Zone 3 is a shady area comprising large trees set close together; sunlight therefore does not reach the whole crown of each tree. As a result, flowering was delayed in 1997 even though trees were located at a lower altitude than those of zone 4. Nevertheless, at the end of 2000 , trees were heavily pruned, and consequently flowering took place earlier in both 2001 and 2002 (fig. 3A).

\section{Sierras Subbéticas: Inter-zone variability}

Figure 3B shows bar charts for the temporal distribution range of male and female phenological phases based buds/ flower pool development in Sierras Subbéticas. In general, the phenophase range differed as a function of the holm-oak zone in Priego de Córdoba. In 1999, trees located on the south-facing hillside flowered first, followed by those in the Watercourse and finally those on the north-facing hillside, although with only a few days' difference. By contrast, in 2000 the first trees to flower were those on the north-facing hillside followed, those in the Watercourse and finally those in south-facing areas. This result is probably due to the lack of the data for 2000 , when only two trees flowered. The 
previous year, these trees were severely damaged by lack of rainfall at the start of autumn, by plant lice and/or by pruning, with the result that in spring 2000 only vegetative buds were produced.

The results obtained in 1999 show that the first trees to flower were those facing south, followed by the trees in the Watercourse and finally north-facing trees. In individual trees, the south-facing part of the crown also flowered first.

Sierras Subbéticas: Inter-annual variability

The flowering period commenced earlier in 2000 than in 1999 (fig. 3B). The total floral phenological range in the various sampling areas in Priego de Córdoba was shorter in 2000 than in 1999, when higher spring temperatures were recorded (fig. 4). The total range of the flowering period was lowest on the north-facing hillside in both years.

Although double flowering was not a general finding in the study area, some $Q$. ilex ssp. ballota trees displayed a second (male o female) flowering period at the start of autumn in 1999.

Table 2 shows the total range of the flowering period for $Q$. ilex ssp. ballota in each sampling zone, for both years, expressed as number of days from 1 January to the end of the flowering period.

\section{Sierra Morena vs. Sierras Subbéticas}

Comparison of $Q$. ilex ssp. ballota floral phenological behaviour in the two main sampling zones in the province of Córdoba in 1999 and 2000 (fig. 3), disclosed that the flowering period in all three study zones in Córdoba lasted from 1 March to 1 April, while in Priego de Córdoba flowering took place in May. The temporal distribution range for floral phenophases in the three Córdoba zones in 2000 ran from 1 March to the second fortnight in April, while in Priego de Córdoba it ran from late April to late May. The start of the $Q$. ilex ssp. ballota flowering period took place later in the higher-altitude Sierras Subbéticas than in Sierra Morena. Phenological ranges in Priego de Córdoba were greater due to the lower temperatures recorded there (fig.4).

\section{DISCUSSION}

Quercus species are monoecious; male and female flowers are produced by the same individual with certain temporal and spatial variations. Vázquez (1998) defines the presence of protogynous or protandrous individuals as reproducing strategies, but in the present study areas, over six years, only protandrous individuals were found. Maturation of male flowers takes place during catkin elongation, since pollen maturation takes place in that phase (Sharp and Chisman 1961; Stairs 1964; Wolgast and Stout 1977). Data for total crown morphology at a given date in all three species showed that the predominant male phenophase tended to overlap with a different female phenophase.

The catkin elongation phase usually overlapped with the female flower differentiation stage, while full flowering and receptivity in the female overlapped with the start of flowering in the male, coinciding with the start of pollen release. Moreover, not all trees in a given population developed at the same speed. Similar findings have been reported for other species, in which the flowering process was not simultaneous between trees or even on a single tree. Oaks are characterized by a high betweenindividual variability that can be attributed to a variety of physical factors of pollen dispersion and to oaks flowering traits (Streiff et al, 1999). This could be a reproductive strategy for enhancing crosses 
between species and individuals (Vázquez 1998); intra-species variation may thus be related to environmental diversity (Latorre and Bianchi 1998; Grime 1979; Aseyev et al., 2005). Moreover, reproductive success and seed formation at a global woodland level is largely determined by the difference in the start of flowering within a mass of trees (Vázquez 1998) and heterogeneity of pollen dispersal (Streiff et al., 1999). This heterogeneity, joined to long-distance gene flow and variability of mating success all contribute to maintain high levels of diversity in oaks stand (Streiff et al., 1999).

Flowers of different Quercus species and populations displayed parallel morphological patterns of phenological development, but the temporal distribution of phenophases differed both between species and between trees of the same species in different sampling zones. Trees in the five selected areas are exposed to different bioclimatic conditions, depending on facing distribution and altitude; as a result, the flowering period started later in zones at a higher altitude. This was particularly evident when comparing the temporal distribution of phenophases of $Q$. ilex ssp. ballota in Córdoba and Priego de Córdoba, where flowering started later and the total phenological range was greater. At the same time, phenological development was also determined by relative position; trees facing south flowered before those facing north. At individual level, the south-facing part of the crown also flowered earlier (Vázquez 1998). Thus, viewing the population as a whole, those individuals whose crowns faced south flowered earlier.

Moreover, $Q$. ilex ssp. ballota in zone 4 flowered later than $Q$. coccifera in all years except 1999, when it flowered earlier. This may have been due to insufficient rainfall prior to the flowering period, which would have a more negative impact on $Q$. coccifera as a shrub not reaching underground water; even though studies in other species suggest that flowering is more strongly influenced by temperature than by rainfall (Spano et al. 1999; Garau et al. 2000; Reeves and Coupland 2000).

Q. suber is commonly referred to in the bibliography as a species with several flowering seasons (Elena-Rosello et al. 1993; Varela and Valdiviesso 1996; DíazFernández et al., 2004). The presence of inflorescences and fruits on new branches indicates an annual reproductive strategy, while their presence on previous-year branches suggests a biennial one. Here, $Q$. suber displayed an annual reproductive pattern over the study period. On the other hand, Díaz-Fernández et al. (2004) reported a relationship between phenology and acorn maturation as influenced by environmental conditions, which determine the annual or biennial pattern. Although double flowering was not a general finding in the study area, some Q. ilex ssp. ballota and Q. suber trees displayed a second (male o female) flowering period at the start of autumn in both 1999 and 2001. This second flowering was probably due to mild temperatures and higher rainfall, following a stress period caused by harsh summer conditions. However, doubleflowering was not completed, and stopped in phenophase $\mathrm{D} / \mathrm{c}$. Double flowering has been reported in the Iberian Peninsula by Curras and Laguna $(1985,1986)$ in Valencia and Vázquez (1998) in Badajoz, in both $Q$. ilex ssp. ballota and $Q$. suber.

Weather conditions prior to flowering and vegetative growth are decisive factors in plant development and it has been observed in Quercus pollen season (GarcíaMozo et al., 2002; García-Mozo et al., 2006). Prolonged dry periods may weaken trees, causing loss of leaves and reducing vegetative growth and thus the possibility of vegetative and floral bud formation 
(Cabezudo et al. 1993; Pérez-Latorre et al. 1996). Moreover, a competitive role exists between reproductive and vegetative phenophases to acquire plant resources (Pérez-Latorre and Cabezudo, 2002). In Priego de Córdoba, trees on the north-facing hillside in 2000 showed signs of damage, and only two produced floral buds, the others produced vegetative buds, probably as a result of dry conditions at the start of the previous autumn.

Reproductive processes taking place in spring in these species are closely related to population dynamics and structure (Vázquez 1998). Most studies in temperate-zone trees species assume that temperature regulates phenological development induced by a chilling period, depending on the species and geographical areas, that induces budburst followed by a period with forcing temperatures (also variable) that releases dormancy and thus triggers the onset of growth (Aron 1982; Hari and Häkkinen 1991; Frenguelli et al. 1992; Kramer 1997; Wielgolaski 1999; Chuine 2000; Fulton et al. 2001; Galán et al. 2001). Once buds have begun to develop, floral structures are exposed to the weather conditions which determine the whole of the phenological process. The catkin elongation phenophase is highly sensitive to sharp change in humidity (Sharp and Chisman 1961). Moreover, adverse temperature conditions recorded during that phase in Quercus gambelii Nutt. (Neilson and Wullstein 1980) and $Q$. suber (García-Mozo et al. 2001) are reported to have a negative effect on the reproductive cycle of the tree, interrupting catkin development, probably due to a sharp drop in minimum temperatures, as occurred here in $Q$. suber in Sierra Morena over three consecutive years (1998, 1999 and 2000) when frosts were recorded in early spring.

The length of each floral phenophase differed between species, zones, years and sexes. Trees located in sunny areas displayed a shorter total phenological range. Moreover, shorter ranges were recorded in years with warmer springs; temperature and solar radiation have been shown to influence the flowering process in these Quercus species (Vázquez 1998). In general, female phases displayed a shorter range. Moreover, slow development in the initial phases was followed by fast changes during the flowering period, with a subsequent slowing down in the final phases.

ACKNOWLEDGEMENTS. The authors are grateful to the Spanish DGICYT for financial support granted through Project PB-96-0513.

\section{REFERENCES}

ARON, R. -1982-Availability of chilling Temperatures in California. Agricultural Meteorology 28, 351-363.

ASEYEV, O.V., D. TISCHIN \& T.H. SPARKS 2005- The effect of climate on the phenology, acorn crop and radial increment of pedunculate oak (Quercus robur) in the middle Volga region, Tatarstan, Russia. Int. J. Biometeorol. 49: 262-266.

CABEZUdo, B., A.V. PÉREZ LATORRE, T. NAVARRO \& J.M. NIETO CALDERA 1993- Estudios fenomorfológicos en la vegetación del sur de España. II. Alcornocales mesomediterráneos. (Montes de Málaga, Málaga). Acta Bot. Malacitana 18: 179-188.

CAMPOS PALACÍN, P. -1991- Economía y conservación de sistemas agrosilvopastorales mediterráneos de dehesas y montados. Valores económicos y ambientales de las dehesas espeñolas. Seminario CEE/CSIC/ SIA/A. Ayuntamiento de Jerez-Badajoz. Jerez de la Frontera (Cádiz).

CHUINE, I. -2000-A Unified Model for Budburst of trees. J. Theor. Biol 207: 337-347.

CURRAS, R. \& E. LAGUNA -1985- Nuevo modelo de representación de los datos fenológicos de la escala de Ellemberg. Bol. 
Soc. Bort., Sér. '2, 58: 259-267.

CURRAS, R. \& E. LAGUNA -1986- Datos sobre la fenología de algunas especies forestales valencianas. Montes. Revista de ámbito forestal 10: 50-52.

DÍAZ-FERNÁNDEZ P.M., J. CLIMENT \& L. GIL -2004- Biennial acorn maturation and its relationship with flowering phenology in Iberian populations of Quercus suber. Trees 18: 615-621.

DUCOUSSO, A.;H. MICHAUD \& R. LUMARET -1993-Reproduction and gene flow in the genus Quercus L.. Ann. Scic. For 50, (supp1): 91-106.

ELENA-ROSELLO, J.A., J.M. DE RÍO GARCÍA, J.L. VALDECANTOS \& I.G. SANTAMARÍA -1993- Ecological aspects of the floral phenology of the cork-oak (Q.suber L.): why do annual an bienal biotypes appear?. Ann Sci For 50, Suppl 1, 114s-121s.

FRENGUELLI, G. E. BRICCI; B. ROMANO, G. MINCIGRUCCI, F. FERRANTI \& E. ANTOGONOZZI -1992- The role of air temperature in determining dormancy release and flowering of Coryllus avellana L. Aerobiología 8: 415-418.

FULTON, T.A., A.J. MAY \& J.L. CATLEY 2001-Chilling requeriments of Paeonia cultivars. Scientia Horticulturae 89: 237-248.

GALÁN, C. H., P. GARCÍA-MOZO, P. CARIÑANOS, ALCÁZAR \& E. DOMÍNGUEZ -2001 - The role of temperature in the onset of the Olea europaea L. pollen season in south-western Spain. Int J Biometeorol 45: 8-12.

GARAU, A., S.F. DE DELFINO \& G. BERRONDO -2000- Influencia de factores climáticos en las fechas de inicio de floración y brotación de clones de Alamo en el delta del Paraná, Argentina. Invest. Agr.: Sist. Recur. For 9(1).

GARCÍA-MOZO, H., C. GALÁN, M.J. AIRA, J. BELMONTE, C. DÍAZ DE LA GUARDIA, D. FERNÁNDEZ, F.J. GUTIERREZ, M.M. TRIGO \& E. DOMÍNGUEZ -2002Modelling start of oak pollen season in different climatic zones in Spain. Agricultural and Forest Meteorology, 110:247- 257.

GARCÍA-MOZO, H., C. GALÁN, V. JATO, J. BELMONTE, C. DÍZ DE LA GUARDIA, D.
FERNÁNDEZ, M. GUTIÉRREZ, M.J. AIRA, J.M. ROURE, L. RUIZ, M.M. TRIGO \& E. DOMÍNGUEZ-VILCHES -2006- Quercus pollen season dynamics in the Iberian Peninsula: response to meteorological parameters and possible consequences of Climate Change. Annal Agriculture and Environmental Medicine, 13:209-224.

GARCÍA-MOZO, H., P. HIDALGO, C. GALÁN, M.T. GÓMEZ-CASERO \& E. DOMÍNGUEZ -2001- Catkin frost damage in Mediterranean cork-oak (Quercus suber L.). Israel Journal of Plant Sciences 49: 41-47.

GRIME, J.P. -1979- Plants strategies and vegetation processes. J. Wiley \& Sons. (Eds.) New York.

HARI, PERTTI \& HÄKKINEN RISTO -1991The utilization of old phenological time series of budburst to compare models describing annual cycles of plants. Tree Physiology 8: 281-287.

JOFFRE, R. -1991- The dehesa: Does this complex ecological system have a future? In: Teller, A.; Mathy, P.; Jeffers, JNR. (eds). Responses of forests ecosystems to environmental changes. Proccedings of the First European Symposium on Terrestrisl Ecosystems: forests and woodlands. Elsevier, London. Pp 381-388.

KAUL, R.B. -1985- Reproductive morphology of Quercus (Fagaceae). American Journal of Botany 72(12): 1962-1977.

KRAMER, K. -1997- Phenology and grouth of Europaean trees in relation to climate exchange 12: 39-50. In. Phenology in seasonal climates I. Series Editor Lieth, H. \& Schwartz, M.D. Backhuys Publishers. Leiden.

LATORRE, F. -1997- Comparison between phenological and aerobiological patterns of some arboreal species of Mar del Plata (Argentina). Aerobiología 13: 49-59.

LATORRE, F. \& M.M. BIANCHI -1998Relatinships between flowering development of Ulmus pumila and Fraxinus excelsior and their airborne pollen. Grana 37: 233-238.

LIETH, H. -1997- Aims and methods in Phenological monitoring. In Phenology in seasonal climates I.. Series Editor Lieth, H. \& Schwartz, M.D. Backhuys Publishers. Leiden. 
MYKING, T. \& O.M. HEIDE -1995- Dormancy release and chilling requeriment of buds of latitudinal ecotypes of Betula pendula and $B$. pubescens. Tree Physiology 15: 697-704.

NEILSON, R.P. \& H. WULLSTEIN -1980Catkin freezing and acorn production in gambel oak in Utah, 1978. Amer. J. Bot 67(3): 426-428.

OLIVEIRA, G., O. CORREIA, M.A. MARTINSLOUÇÁO \& F.M. CATARINO -1994Phenological and growth patterns of the Mediterranean oak Quercus suber L. Trees 9:41-46.

ORSHAN, G. -1989- Plant pheno-morphological studies in Mediterranean type ecosystems. Dordrecht: Kluwer Publisher, The Netherlands.

PÉREZ LATORRE, A.V., B. CABEZUDO, J.M NIETO CALDERA. \& T. NAVARRO -1996Caracterización fenológica y ecomorfológica de alcornocales andaluces (Málaga, España). Anales Jard. Bot. Madrid 54(1): 554-560.

PÉREZ LATORRE, A.V. \& B. CABEZUDO 2002- Use of monocharacteristic growth forms and phenological phases to describe and differentiate plant communities in Mediterranean-type ecosystems. Plant Ecology 161: 231-249.

PÉREZ LATORRE, A.V \& B. CABEZUDO 2006- Phenomorphology and ecomorphological characters of Rhododendron lauroid forests in the Western Mediterranean (Iberian Peninsula, Spain). Plant Ecology 187: 227-247.

PUPPI BRANZI, G. \& A.L. ZANOTTI -1992Estimate and mapping of the activity of airborne pollen sources. Aerobiologia 8: 6974.

REEVES, P.H. \& G. COUPLAND -2000- Response of plant development to environment: control of flowering by daylength and temperature. Current opinion in Plant Biology 3: 37-42.

SCHWARTZ, M.D. -1999- Advancing to full bloom: planning phenological research for the twenty-first century. Int $J$ Biometeorol 42:113-118.

SCHWARTZ, M.D. -2003- Phenology: an Integrative Environmental Science. Kluwer
Academic Pulishers.

SHARP, W.M. \& H.H., CHISMAN -1961Flowering and fruitting in the white oaks. I: Staminate flowering through pollen dispersal. Ecology 42 (2): 365-372.

SPANO, D. C. CESARACCIO, P. DUCE \& R.L. SNYDER -1999- Phenological stages of natural species and their use as climate indicators. Int J Biometeorol 42: 124-133.

SPARKS, T.H., E.P. JEFFREE \& C.E. JEFFREE -2000- An examination of the relationship between flowering times and temperature at the national scale using long-term phenological records from the UK. Int $J$ Biometeorol 44: 82-87.

STAIRS, G.R. -1964- Microsporogenesis and embryogenesis in Quercus. Bot. Gaz. 125: 115-121.

STREIFF, R., A. DUCOUSSO, C. LEXER; H. STEINKELLNER, GLOESSL, A. KREMER INRA- 1999- Pollen dispersal inferred from paternity analysis in a mixed oak stand of Quercus robur L. and Q. petraea (Matt.) Liebl. Molecular Ecology 8: 831-841.

VARELA, M.C. \& T. VALDIVIESSO -1996Phenological phases of Quercus suber L. Flowering. Forest Genetics 3(2): 93-102.

VÁZQUEZ PARDO, F.M. -1998- Semillas del género Quercus L. (Biología, Ecología y Manejo). Servicio de Investigación y Desarrollo Tecnológico. Junta de Extremadura. Consejería de Agricultura y Comercio.

WIELGOLASKI, F.E. -1999- Starting dates and basic temperatures in phenological observations of plants. Int. J. Biometeorol. 42: 158-168.

WOLGAST, L.J. \& B.B. STOUT -1977- The effects of relative humidity at the time of flowering on fruti set in bear oak (Quercus ilicifolia). Amer. J. Bot. 64(2): 159-160.

ZERBONI, R., P.V. ARRIGONI, M. MANFREDI, M. RIZZOTTO, L. PAOLETTI \& C. RICCERI -1991- Geobotanical and phonological monitoring of allergenic pollen grains in the Florence area. Grana 30: 357363. 